\title{
Sex Estimation Using Ulna in a Thai Population
}

\author{
Estimación del Sexo Utilizando la Ulna en una Población Tailandesa
}

\author{
Tawachai Monum'; Wiraporn Jongmuenwai'; Siriwat Thunyacharoen²; \\ Apichat Sinthubua $^{2,4}$; Sukon Prasitwattanaseree ${ }^{3} \&$ Pasuk Mahakkanukrauh $^{2,4}$
}

\author{
MONUM, T.; JONGMUENWAI, W.; THUNYACHAROEN, S.; SINTUHBUA, A.; PRASITWATTANASEREE, S. \& \\ MAHAKKANUKRAUH, P. Sex estimation using ulna in a Thai population. Int. J. Morphol., 39(6):1535-1542, 2021.
}

SUMMARY: Sex estimation from fragmentary bone remain is still challenge for forensic pathologist. Ulna has been reported useful for sex estimation by metric analysis. This study generated sex estimation function for fragment and complete of ulnar bone in a Thai population. The function was generated from 200 pairs of ulnar bone, and others 20 pair of ulnar bone were used for test the accuracy of the functions. Olecranon width was the best single variable for sex predicting of proximal part of ulna, which right olecranon width could be classified the sex $90.5 \%$. While distal end width of ulna was the variable for predicting the sex of distal part, which left distal end width could be classified the sex with $83.0 \%$. Stepwise discriminant function analysis was applied to proximal part. For proximal part of right ulna 4 measurements were selected (inferior-medial trochlear notch length, olecranon width, olecranon-coronoid process length, and maximum proximal ulnar width), while the left side, superior trochlear notch width, olecranon width, and maximum proximal ulnar width were chosen, and their functions could be predicted the sex with $91.0 \%$ and $90.0 \%$, respectively. Our results indicated the ulnar bone had high ability for estimating the sex in a Thai population.

KEY WORDS: Discriminant function analysis; Metric analysis; Sex estimation; Thailand; Ulna.

\section{INTRODUCTION}

Personal identification in forensic science is a multiscientific knowledge that used for verifying the unknown human remains. The subject of personal identification may be a decease, dismemberment, blood strain, and skeletal remain. Presently, fingerprint analysis, DNA profiling, and dental profile are well known as primary criteria of disaster victim identification method, which have high potential for positive identification (Sweet, 2010). However, these methods need to find the possible missing persons before matching which the unknown body remain.

Biological profiles analysis, which compose of sex, age, stature, and ethic, assist to reduce the numbers of possible missing persons before matching to the unknown decease. Sex estimation is a crucial step for biological profile analysis process because accurate sex estimation will reduce the number of possible missing person at around $50 \%$, and age and stature analysis are depend on their sex (Di Gangi \& Moore, 2013). Currently, sex estimation using os coxa is known as the gold standard method for estimating sex (Klepinger, 2006). However, in forensic context, os coxae might not recover or not be well preserved enough to estimate sex due to the taphonomic and scavenging process. Thus, sex estimation from other bone is still required.

Metric analysis of long bones dimension have been stated the high percentage of accuracy method (Christensen et al., 2019). The combination measurement of various dimension of long bone could be estimate sex with higher percentage accuracy than those of skull (Spradley \& Jantz, 2011). Ulna was a long bone that demonstrated high sexual dimorphism, and various dimension measurement of them have been used for estimate the sex in many population (Safont et al., 2000; Mall et al., 2001; Sakaue, 2004; Barrier \& L'Abbé, 2008; Charisi et al., 2011; Uzün et al., 2011; Srivastava et al., 2013; Kearns, 2015). For instance, maximum length of ulna could determine the sex with 84.9 $\%$ of accuracy in Indian population (Waghmare et al., 2012). However, sex estimation using metric analysis method is definite to the sampling population. Therefore, sex estimation

\footnotetext{
${ }^{1}$ Department of Forensic Medicine, Faculty of Medicine, Chiang Mai University, Chiang Mai, Thailand.

${ }^{2}$ Department of Anatomy, Faculty of Medicine, Chiang Mai University, Chiang Mai, Thailand.

${ }^{3}$ Department of Statistics, Faculty of Science, Chiang Mai University, Chiang Mai, Thailand.

${ }^{4}$ Excellence Center in Osteology Research and Training Center (ORTC), Chiang Mai University, Chiang Mai, Thailand.
} 
method of a population may not suitable for others population.

There wasa report of sex estimation by using complete ulna in the northern Thai population, which could predict the sex with $90.0 \%$ of accuracy (Suwanlikhit, 2003). However, in the forensic context, ulnar bone might be recovered as the fragmented condition because of decomposition process and carnivore animals' activity, consequently, previous method may not proper for the fragmentary bone remain. In addition, there were some ulna's dimension that has not been studied for estimating the sex in Thai population. Therefore, the aim of this study is to establish the new specific sex estimation method for the fragmentary and complete of ulnar bone in a Thai population.

\section{MATERIAL AND METHOD}

Samples. The sampling was conducted randomly in a Thai skeleton with 200 left-right pairs of ulnae (100 males and 100 females) from the Forensic Osteology Research Center (FORC), Department of Anatomy, Faculty of Medicine, Chiang Mai University, Thailand. The source of ulnar bones was donated cadavers, which were born in 20th century and lived in the northern region of Thailand. The mean age for male samples was 63.92 years old (range19-90 years old); the mean age for female samples was 63.37 years old (range 29-91 years old). The samples that demonstrate traumatic or pathological lesion such as traumatic fracture, osteoporosis, congenital anomalies, bone cancer, were excluded from this study. In addition, the other 20 pairs of ulnae from the same collection were randomly chosen for evaluating the accuracy of sex estimation function. The ethic of this study was approved by the Research Ethics Committee of Chiang Mai University.

Measurements. Morphometric location of the ulnar bone from various anatomical landmarks were considered and studied. To locate the landmarks, various parameters were measured with accuracy digital vernier caliper (mm unit) on the ulna on both sides as in Figure 1. The detail of the measurements was descripted as following:

1. Superior-medial trochlear notch lengthis the distance from the center of the top edge of the olecranon process (A) to the most medial edge of the trochlear notch (B) (Suwanlikhit).

2. Inferior-medial trochlear notch length is the distance from the center of the top edge of the coronoid process (D) to the most medial edge of the trochlear notch (E) (Suwanlikhit). 3. Olecranon width is the distance from the most medial edge (B) to the most lateral edge of the trochlear notch (C) (Cowal \& Pastor, 2008).

4. Superior trochlear notch width is the distance from the center of the top edge of the olecranon process (A) to the center of the trochlear notch (F) (Purkait, 2001).

5. Inferior trochlear notch width is the distance from the center of the top edge of the coronoid process (D) to the center of the trochlear notch (F) (Purkait).

6. Olecranon-coronoid process length is the distance from the center of the top edge of the olecranon process (A) to the center of the top edge of the coronoid process (D) (Uzün et al.).

7. Coronoid height is the distance from the center of the top edge of the coronoid process (D) to dorsal surface of proximal ulnar bone (I) (Cowal \& Pastor).

8. Maximum proximal ulnar width is the widest of proximal ulnar bone (L-M) (Mall et al.).

9. Ulnar notch length is the distance from the edge on the top of the lateral olecranon process $(\mathrm{G})$ to the bottom edge of the radial notch of the ulnar bone $(\mathrm{H})$ (Cowal \& Pastor).

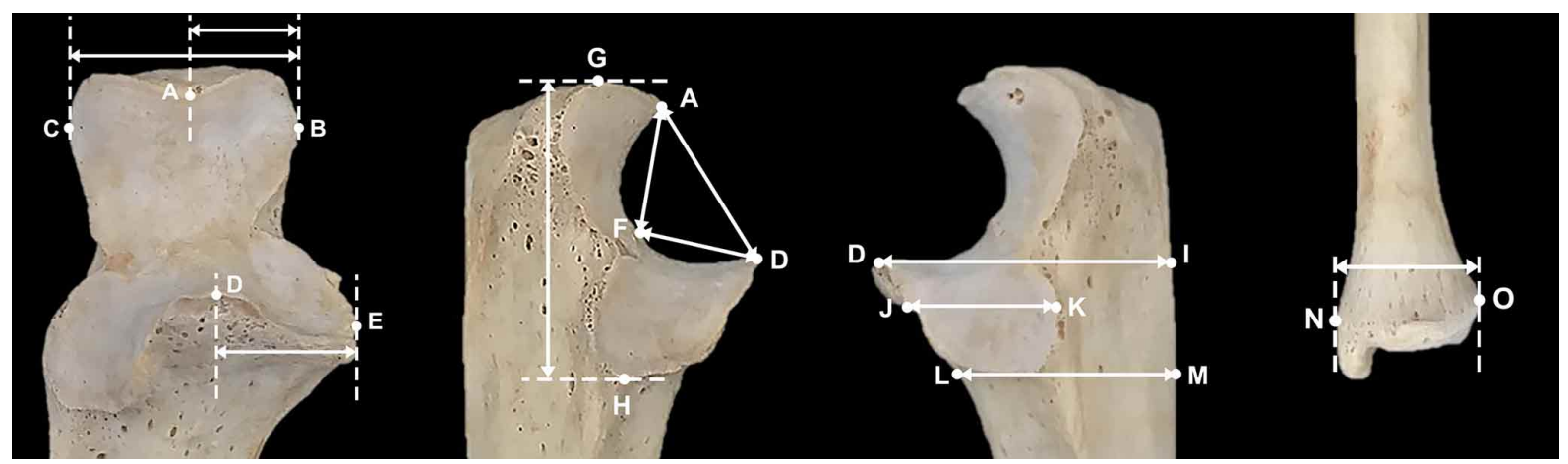

Fig. 1. Parameters measurements from various anatomical landmarks of ulna. 
10. Ulnar radial notch width is the distance from the most ventral edge of the radial notch (J) to the most dorsal edge of the radial notch of the ulnar bone (K) (Cowal \& Pastor). 11. Ulnar distal end width is the widest of the distal end of the ulnar bone (N-O) (Uzün et al.).

Statistical Analysis. Descriptive statistics presented the minimum value, the maximum value, the mean and standard deviation of each variable that obtained from the measurement of ulnar bone on both sides. The different between size of male and female ulnar' dimension was evaluated by the independent t-test, and normality of the data were verified by 1 sample Kolmogorov-Smirnov statistic. The significant statistic difference between sexes of the measurements were conducted to direct and stepwise discriminant function analysis. For the stepwise method, all selected variables were entered into a stepwise discriminant function procedure using Wilks' lambda, to define which variables provided the best discrimination between male and female groups. The accuracy of stepwise discriminant functions was evaluated by the percentage of accuracy. Significant statistics significant were observed at value below 0.05 and all data were analyzed by SPSS v.22.

Twenty pairs ulnar, which including 10 females and 10 males were sampling, from the original samples were used for testing the observer error.The intra-and inter-observer errors were analyzed by the technical error of measurement (TEM), relative technical error of measurement (rTEM), and coefficient of reliability (R) (Knapp, 1992; Weinberg et al., 2005).

\section{RESULTS}

The result of the observation error was demonstrated in Table I. The relative TEM of all parameters are acceptable (relative TEM $\leq 1.5 \%$ ) and coefficient of reliability (R) of all parameters are high with $0.965-0.999$. Intra-observer error presents the relative TEM of all parameters are acceptable (relative TEM $\leq 2.0 \%$ ) with the range of $\mathrm{R}$ value is $0.940-0.994$.

All measurements of males indicated significant statistic larger than those of females (Table II), and most of variables showed significant different between left and right side, except olecranon-coronoid process length, coronoid height and ulnar notch length (Table II). The results of 1 sample Kolmogorov-Smirnov test indicated all variables were found in a normal distribution. Consequently, the discriminant functions were generated separately between left and right side (Table III).

Table I. Technical error of measurement and coefficient of reliability of intra and inter-observer error.

\begin{tabular}{|c|c|c|c|c|c|c|c|}
\hline \multirow[t]{2}{*}{ Measurement } & \multirow[t]{2}{*}{ Side } & \multicolumn{3}{|c|}{ Intra-observer error } & \multicolumn{3}{|c|}{ Inter-observer error } \\
\hline & & $\begin{array}{l}\text { TEM } \\
(\mathrm{mm} .)\end{array}$ & $\begin{array}{l}\text { Rela tive } \\
\text { TEM ( \%) }\end{array}$ & $\mathrm{R}$ & $\begin{array}{l}\text { TEM } \\
(\mathrm{mm} .)\end{array}$ & $\begin{array}{c}\text { Relative } \\
\text { TEM ( \%) }\end{array}$ & $\mathrm{R}$ \\
\hline \multirow[t]{2}{*}{ Superior-medial trochlear notch length } & $\mathrm{L}$ & 0.24 & 1.41 & 0.985 & 0.27 & 1.57 & 0.972 \\
\hline & $\mathrm{R}$ & 0.23 & 1.29 & 0.988 & 0.20 & 1.14 & 0.980 \\
\hline \multirow[t]{2}{*}{ Superiortrochlear notch width } & $\mathrm{L}$ & 0.13 & 0.82 & 0.993 & 0.27 & 1.79 & 0.967 \\
\hline & $\mathrm{R}$ & 0.22 & 1.43 & 0.978 & 0.29 & 1.81 & 0.978 \\
\hline \multirow[t]{2}{*}{ Inferior-medial trochlear notch length } & $\mathrm{L}$ & 0.22 & 1.02 & 0.990 & 0.26 & 1.27 & 0.983 \\
\hline & $\mathrm{R}$ & 0.22 & 1.02 & 0.990 & 0.30 & 1.42 & 0.975 \\
\hline \multirow[t]{2}{*}{ Inferiortrochlear notch width } & $\mathrm{L}$ & 0.23 & 1.49 & 0.965 & 0.30 & 1.94 & 0.943 \\
\hline & $\mathrm{R}$ & 0.22 & 1.38 & 0.975 & 0.29 & 1.83 & 0.944 \\
\hline \multirow[t]{2}{*}{ Olecranon width } & $\mathrm{L}$ & 0.12 & 0.55 & 0.998 & 0.25 & 1.12 & 0.987 \\
\hline & $\mathrm{R}$ & 0.10 & 0.45 & 0.999 & 0.19 & 0.86 & 0.994 \\
\hline \multirow[t]{2}{*}{ Olecranon-coronoid process length } & $\mathrm{L}$ & 0.21 & 0.92 & 0.986 & 0.27 & 1.17 & 0.969 \\
\hline & $\mathrm{R}$ & 0.22 & 0.97 & 0.987 & 0.26 & 1.16 & 0.973 \\
\hline \multirow[t]{2}{*}{ Coronoid height } & $\mathrm{L}$ & 0.20 & 0.59 & 0.994 & 0.26 & 0.78 & 0.988 \\
\hline & $\mathrm{R}$ & 0.20 & 0.12 & 0.994 & 0.20 & 0.59 & 0.994 \\
\hline \multirow[t]{2}{*}{ Maximum proximal ulnar width } & $\mathrm{L}$ & 0.24 & 1.07 & 0.990 & 0.34 & 1.51 & 0.974 \\
\hline & $\mathrm{R}$ & 0.23 & 0.96 & 0.990 & 0.29 & 1.25 & 0.983 \\
\hline \multirow[t]{2}{*}{ Ulnar notch length } & $\mathrm{L}$ & 0.16 & 0.48 & 0.996 & 0.31 & 0.93 & 0.981 \\
\hline & $\mathrm{R}$ & 0.19 & 0.56 & 0.995 & 0.26 & 0.78 & 0.987 \\
\hline \multirow[t]{2}{*}{ Ulnar radial notch width } & $\mathrm{L}$ & 0.22 & 1.18 & 0.987 & 0.33 & 1.83 & 0.940 \\
\hline & $\mathrm{R}$ & 0.19 & 1.00 & 0.990 & 0.30 & 1.63 & 0.949 \\
\hline \multirow[t]{2}{*}{ Ulnar distal end width } & $\mathrm{L}$ & 0.12 & 0.66 & 0.994 & 0.24 & 1.32 & 0.964 \\
\hline & $\mathrm{R}$ & 0.11 & 0.61 & 0.995 & 0.18 & 0.96 & 0.983 \\
\hline
\end{tabular}


The accuracy of sex estimation function using single dimension of ulna were range from $71.5-90.5 \%$ (Table III), and only half of variables provided the accuracy of sex estimation function more than $80.0 \%$. The highest accuracy rate of sex estimation function was derived from olecranon width, which the percentage of the accuracy of right and left side were $90.5 \%$ and $89.5 \%$, respectively. Right inferiormedial trochlear notch length and right ulnar notch length were in the second and third order which the percentage of accuracy from these dimensions were $87.5 \%$ and $87.0 \%$, respectively. While the function that generated by right ulnar radial notch width provided the lowest percentage of the accuracy as $71.5 \%$.

Stepwise discriminant function analysis (Table IV) was applied to proximal part. Right proximal part indicated higher ability to estimate the sex than those of left proximal part. The right proximal ulna indicated higher percentage of accuracy than left proximal, which were $91.0 \%$ and 90.0 $\%$, respectively. For right proximal ulna, inferior-medial trochlear notch length, olecranon width, olecranoncoronoid process length, and maximum proximal ulnar width were selected to sex estimation model while superior trochlear notch width, olecranon width, maximum proximal ulnar width were chosen for the left side.

The section point of discriminant function was 
Table III. Direct discriminant function, percent of accuracy and corrected percentage of accuracy.

\begin{tabular}{|c|c|c|c|c|c|c|c|}
\hline \multirow[t]{2}{*}{ Function } & \multirow[t]{2}{*}{ Variables } & \multirow{2}{*}{$\begin{array}{l}\text { Unst andardized } \\
\text { Coefficients }\end{array}$} & \multirow[t]{2}{*}{ Group centroid } & \multirow[t]{2}{*}{ Predicted group } & \multicolumn{3}{|c|}{ Accuracy study group ( \%) } \\
\hline & & & & & Males & Females & Total \\
\hline \multirow[t]{2}{*}{1} & Left Superior-medial trochlear notch length & 0.638 & $\mathrm{M}=0.768$ & Original & 80.0 & 80.0 & 80.0 \\
\hline & Constant & -11.021 & $F=-0.768$ & Cross-validated & 80.0 & 80.0 & 80.0 \\
\hline \multirow[t]{2}{*}{2} & Right Superior-medial trochlear notch length & 0.629 & $\mathrm{M}=0.838$ & Original & 79.0 & 80.0 & 79.5 \\
\hline & Constant & -11.154 & $F=-0.838$ & Cross-validated & 79.0 & 80.0 & 79.5 \\
\hline \multirow[t]{2}{*}{3} & Left Superior trochlear notch width & 0.938 & $M=0.939$ & Original & 84.0 & 82.0 & 83.0 \\
\hline & Constant & -14.403 & $F=-0.939$ & Cross-validated & 84.0 & 82.0 & 83.0 \\
\hline \multirow[t]{2}{*}{4} & Right Superior trochlear notch width & 0.879 & $\mathrm{M}=0.874$ & Original & 83.0 & 81.0 & 82.0 \\
\hline & Constant & -13.760 & $F=-0.874$ & Cross-validated & 83.0 & 81.0 & 82.0 \\
\hline \multirow[t]{2}{*}{5} & Left Inferior-medial trochlear notch length & 0.599 & $\mathrm{M}=0.863$ & Original & 84.0 & 80.0 & 82.0 \\
\hline & Constant & -12.684 & $F=-0.863$ & Cross-validated & 84.0 & 80.0 & 82.0 \\
\hline \multirow[t]{2}{*}{6} & Right Inferior-medial trochlear notch length & 0.662 & $\mathrm{M}=1.086$ & Original & 85.0 & 90.0 & 87.5 \\
\hline & Constant & -14.207 & $F=-1.086$ & Cross-validated & 85.0 & 90.0 & 87.5 \\
\hline \multirow[t]{2}{*}{7} & Left Inferior trochlear notch width & 0.921 & $M=0.605$ & Original & 75.0 & 74.0 & 74.5 \\
\hline & Constant & -14.417 & $F=-0.605$ & Cross-validated & 75.0 & 73.0 & 74.0 \\
\hline \multirow[t]{2}{*}{8} & Right Inferior trochlear notch width & 0.894 & $\mathrm{M}=0.732$ & Original & 79.0 & 80.0 & 79.5 \\
\hline & Constant & -14.132 & $F=-0.732$ & Cross-validated & 77.0 & 80.0 & 78.5 \\
\hline \multirow[t]{2}{*}{9} & Left Olecranon width & 0.572 & $\mathrm{M}=1.074$ & Original & 91.0 & 88.0 & 89.5 \\
\hline & Constant & -12.895 & $F=-1.074$ & Cross-validated & 91.0 & 88.0 & 89.5 \\
\hline \multirow[t]{2}{*}{10} & Right Olecranon width & 0.536 & $\mathrm{M}=1.173$ & Original & 89.0 & 92.0 & 90.5 \\
\hline & Constant & -12.224 & $F=-1.173$ & Cross-validated & 89.0 & 92.0 & 90.5 \\
\hline \multirow[t]{2}{*}{11} & Left Olecranon-coronoid process length & 0.637 & $M=0.482$ & Original & 72.0 & 74.0 & 73.0 \\
\hline & Constant & -14.269 & $F=-0.482$ & Cross-validated & 72.0 & 74.0 & 73.0 \\
\hline \multirow[t]{2}{*}{12} & Right Olecranon-coronoid process length & 0.607 & $\mathrm{M}=0.591$ & Original & 69.0 & 77.0 & 73.0 \\
\hline & Constant & -13.495 & $F=-0.591$ & Cross-validated & 69.0 & 77.0 & 73.0 \\
\hline \multirow[t]{2}{*}{13} & Left Coronoid height & 0.538 & $\mathrm{M}=1.002$ & Original & 78.0 & 84.0 & 81.0 \\
\hline & Constant & -17.987 & $F=-1.002$ & Cross-validated & 78.0 & 83.0 & 80.5 \\
\hline \multirow[t]{2}{*}{14} & Right Coronoid height & 0.519 & $M=0.955$ & Original & 77.0 & 81.0 & 79.0 \\
\hline & Constant & -17.386 & $F=-0.955$ & Cross-validated & 77.0 & 80.0 & 78.5 \\
\hline \multirow[t]{2}{*}{15} & Left Maximum proximal u lnar width & 0.544 & $\mathrm{M}=0.847$ & Original & 82.0 & 77.0 & 79.5 \\
\hline & Constant & -12.277 & $F=-0.847$ & Cross-validated & 81.0 & 77.0 & 79.0 \\
\hline \multirow[t]{2}{*}{16} & Right Maximum proximal ulnarwidth & 0.572 & $\mathrm{M}=0.839$ & Original & 77.0 & 81.0 & 79.0 \\
\hline & Constant & -13.605 & $F=-0.839$ & Cross-validated & 77.0 & 80.0 & 78.5 \\
\hline 17 & Left ulnar notch length & 0.502 & $\mathrm{M}=0.813$ & Original & 79.0 & 80.0 & 79.5 \\
\hline & Constant & -16.838 & $F=-0.813$ & Cross-validated & 78.0 & 80.0 & 79.0 \\
\hline 18 & Right ulnar notch length & 0.507 & $\mathrm{M}=1.014$ & Original & 90.0 & 85.0 & 87.5 \\
\hline & Constant & -17.102 & $F=-1.014$ & Cross-validated & 90.0 & 84.0 & 87.0 \\
\hline 19 & Left ulnar radial notch width & 0.618 & $\mathrm{M}=0.608$ & Original & 69.0 & 78.0 & 73.5 \\
\hline & Constant & -11.249 & $F=-0.608$ & Cross-validated & 69.0 & 78.0 & 73.5 \\
\hline 20 & Right ulnar radial notch width & 0.619 & $\mathrm{M}=0.639$ & Original & 64.0 & 80.0 & 72.0 \\
\hline & Constant & -11.795 & $F=-0.639$ & Cross-validated & 64.0 & 79.0 & 71.5 \\
\hline 21 & Left ulnar dis tal end width & 0.894 & $\mathrm{M}=0.911$ & Original & 78.0 & 89.0 & 83.5 \\
\hline & Constant & -16.356 & $F=-0.911$ & Cross-validated & 78.0 & 88.0 & 83.0 \\
\hline 22 & Right ulnar distal end width & 0.849 & $\mathrm{M}=0.874$ & Original & 78.0 & 87.0 & 82.5 \\
\hline & Constant & -15.807 & $F=-0.874$ & Cross-validated & 77.0 & 87.0 & 82.0 \\
\hline
\end{tabular}

calculated from the average of the summation of group centroid value. In present study the section point of all functions were 0 , thus if the result of discriminant function analysis was more than 0 the sample would be classified as male whereas if the result was less than 0 the prediction would be female. The results of multiple discriminant function analysis when applied to the test samples also indicated proximal part showed higher ability for estimate the sex than distal part. However, the percentage of accuracy of left side were better than those of right side, which the left proximal ulna can predict the sex with 95 and 90 percentage of accuracy, respectively (Table IV). 
MONUM, T.; JONGMUENWAI, W.; THUNYACHAROEN, S.; SINTHUbUA, A.; PRASITWATTANASEREE, S. \& MAHAKKANUKRAUH, P. Sex estimation using ulna in a Thai population. Int. J. Morphol., 39(6):1535-1542, 2021.

Table IV. Stepwise discriminant function, percent of accuracy and corrected percentage of accuracy.

\begin{tabular}{|c|c|c|c|c|c|c|c|c|c|c|}
\hline \multirow[t]{2}{*}{ Function } & \multirow[t]{2}{*}{ Variables } & \multirow{2}{*}{$\begin{array}{l}\text { Unstandardized } \\
\text { Coefficients }\end{array}$} & \multirow{2}{*}{$\begin{array}{l}\text { Group } \\
\text { centroid }\end{array}$} & \multirow{2}{*}{$\begin{array}{l}\text { Predicted } \\
\text { group }\end{array}$} & \multicolumn{3}{|c|}{ Accuracy study group ( \%) } & \multicolumn{3}{|c|}{ Accuracy test group ( $\%$ ) } \\
\hline & & & & & Males & Females & $\begin{array}{c}\text { Tota } \\
1\end{array}$ & Males & Females & $\begin{array}{c}\text { Tota } \\
1\end{array}$ \\
\hline \multirow[t]{2}{*}{1} & Left ulna (proximal part) & 0.362 & $\mathrm{M}=1.317$ & Original & 92.0 & 89.0 & 90.5 & 90.0 & 100.0 & 95.0 \\
\hline & $\begin{array}{l}\text { Superior trochlear notch } \\
\text { width Olecranon width } \\
\text { Maximum proximal width } \\
\text { Constant }\end{array}$ & $\begin{array}{c}0.356 \\
0.183 \\
-17.726\end{array}$ & $\begin{array}{l}\mathrm{F}=- \\
1.317\end{array}$ & $\begin{array}{l}\text { Cross- } \\
\text { validated }\end{array}$ & 91.0 & 89.0 & 90.0 & & & \\
\hline \multirow[t]{2}{*}{2} & Left ulna (distal part) & 0.894 & $\mathrm{M}=0.911$ & Original & 78.0 & 89.0 & 83.5 & 90.0 & 100.0 & 95.0 \\
\hline & $\begin{array}{l}\text { Distal end width } \\
\text { Constant }\end{array}$ & -16.356 & $\begin{array}{l}F=- \\
0.911\end{array}$ & $\begin{array}{l}\text { Cross- } \\
\text { validated }\end{array}$ & 78.0 & 88.0 & 83.0 & & & \\
\hline \multirow[t]{7}{*}{3} & Right ulna (proximal part) & 0.174 & $\mathrm{M}=1.433$ & Original & 90.0 & 94.0 & 92.0 & 80.0 & 100.0 & 90.0 \\
\hline & Inferior-medial trochlear & & $\mathrm{F}=-$ & Cross- & 89.0 & 93.0 & 91.0 & & & \\
\hline & notch length & 0.314 & 1.433 & validated & & & & & & \\
\hline & Olecranon width & 0.158 & & & & & & & & \\
\hline & Olecranon-coronoid & & & & & & & & & \\
\hline & process length & 0.209 & & & & & & & & \\
\hline & $\begin{array}{l}\text { Maximum proximal width } \\
\text { Constant }\end{array}$ & -19.381 & & & & & & & & \\
\hline \multirow[t]{3}{*}{4} & Right ulna (distal part) & 0.849 & $\mathrm{M}=0.874$ & Original & 78.0 & 87.0 & 82.5 & 80.0 & 100.0 & 90.0 \\
\hline & Distal end width & -15.807 & $F=-$ & Cross- & 77.0 & 87.0 & 82.0 & & & \\
\hline & Constant & & 0.874 & validated & & & & & & \\
\hline
\end{tabular}

\section{DISCUSSION}

Identification of the fragmented skeletal remain is still challenging for forensic medicine. According to our result fragmented of ulna could be used for estimating the sex with high percentage of accuracy. The multivariate discriminant function of proximal could be estimate the sex with 90-91 percentage of accuracy, and the proximal ulna indicated higher sex dimorphism than those of distal ulna in Thai population.

The percentage of accuracy of multivariate discriminant function of ulna in our study was consistent with previous studies and higher than previous study of sex estimation using complete ulna in Thai population, which the accuracy rate of complete ulna was $90.0 \%$ (Table V). In addition, the dimension of superior-medial trochlear notch length, superior trochlear notch width, inferior-medial trochlear notch length, inferior trochlear notch width, olecranon width, and distal end width in our study tent to larger than previous study in Thai population (Suwanlikhit). The larger of size in present sample might explain by the secular trend in Thai population, which the size of bone is increase from the changes of environment and nutrition and

Table V. Comparison of the ulna parameters and accuracy percentage with other studies.

\begin{tabular}{|c|c|c|c|c|}
\hline Study & Population & $\begin{array}{l}\text { Number of } \\
\text { Samples }\end{array}$ & Parameters & $\begin{array}{l}\text { Maximum accuracy } \\
\text { to sex identification }\end{array}$ \\
\hline Purkait (2001) & Indian & 160 & $\begin{array}{l}\text { olecranon-coronoid angle, length of inferior } \\
\text { medial trochlear notch }\end{array}$ & $90.0 \%$ \\
\hline Suwanlikhit (2003) & Thais & 200 & $\begin{array}{l}\text { Right ulna: distal end width, we ight, length of } \\
\text { inferior medial trochlear notch, width of superior } \\
\text { medial trochlear notch }\end{array}$ & $90.0 \%$ \\
\hline Srivastava et al. (2013) & Indian & 106 & maximum length, notch length, radial notch height & $92.5 \%$ \\
\hline Cowal \& Pastor (2008) & British & 223 & notch length, width of the olecranon process & $85.4 \%$ \\
\hline \multirow[b]{2}{*}{ This study (2021) } & \multirow[b]{2}{*}{ Thais } & 200 & left distal end width & $83 \%$ \\
\hline & & 200 & $\begin{array}{l}\text { right ulna: inferior-medial trochlear notch length, } \\
\text { olecranon width, olecranon-coronoid length, } \\
\text { maximum proximal ulnar width }\end{array}$ & $91.0 \%$ \\
\hline
\end{tabular}


these cause the height of Thai population is higher than the past (Seubsman \& Sleigh, 2009; Jordan et al., 2012; Jaruratanasirikul \& Sriplung, 2015). In addition to the changes of the bone size, the different of variables might affect the accuracy of the function.

The dimensions of ulna in this study were different than those of other population. The inferior-medial trochlear notch length and inferior trochlear notch width were larger than Indian population (Purkait), and the olecranon width was also larger than Indian but smaller than South African and post medieval European population (Purkait; Barrier \& L'Abbé; Cowal \& Pastor). As same as olecranon width, coronal height and notch length were also smaller than post medieval European remains but larger than Indian population (Cowal \& Pastor ; Srivastava et al.). Maximum proximal end ulnar width and was smaller than German and Greek while radial notch length was larger Japanese and Indian (Mall et al.; Sakaue; Charisi et al.; Srivastava et al.). The distal end width was also smaller than German but larger than Greek, Turkish, Japanese and Indian (Mall et al.; Sakaue; Charisi et al.; Uzün et al.; Srivastava et al.).

Proximal ulna has been reported as usefulness tools for sex estimation. According to our results olecranon width was the best single measurement for predicting the sex, and this results was similar the study in post medieval European population, but the accuracy rate of our study was higher than that of post medieval European samples, which was $85.4 \%$ (Cowal \& Pastor). However our results were different from the study a Indian sample, which radial notch width showed the higher number of the accuracy rate (Cowal \& Pastor; Srivastava et al.). The multiple discriminant analysisof proximal ulna in this study provided the percentage of accuracy more than $90.0 \%$ for both side, and this accuracy rate was similar to the Purkait's method, which was studied in Indian population, but higher than the study in post medieval European samples (Purkait; Cowal \& Pastor). On the contrary, distal ulna indicated inferior ability for sex estimation than the proximal ulna. Distal end width provided the accuracy rate of sex estimation lower than 85.0 $\%$ for both side, however the ability of sex estimation of distal end width in this study was higher than the studies in German and Greek that rate of accuracy lower than $80.0 \%$ (Mall et al.; Uzün et al.). According to our result, it might suggest that the proximal and distal ulna in Thai population had high sexual dimorphism.

The results elucidated the ulna bones in the Thai population are asymmetric. The right ulna is larger than left side. This might cause people to tend to use the right side of arm in the daily activities. Therefore, the mechanical stress applying to right arm is much more than those of left arm, resulting in the greater dimension. Except to the activity levels, the patterns of bone growth and remodeling are also affected in bone asymmetry (Ruff \& Jones, 1981).

In addition, the percent of accuracy of discriminant function in upper part of ulna was higher than distal part. This might be associated with the different function of male and female's elbow, and the morphology of female's elbow joint is more distinction valgus angulation than that of male.The anatomical and functional of proximal ulna are more relate to the elbow than those of distal ulnar (Sakaue). This might be the reason of higher sexual dimorphism in proximal part than those of distal part of ulnar.

\section{CONCLUSION}

The ulnar bone indicated the high ability for estimating the sex in Thai population. This study providedthe functions that can be used in cases of fragmented and complete ulnar bone for Thai population, and the sex estimation function of many measurements could be determine the sex with the percentage of accuracy was more than $85.0 \%$. The stepwise discriminant function analysis of proximal ulna could be improved the accuracy of functions to more than 90 percentage of accuracy. However, there were the changes of bone size of Thai population according to the time. Consequently, the sex estimation method needed to be continuously updated.

\section{ACKNOWLEDGEMENTS}

The authors sincerely thank and pay great respect to the individuals and families who donated bodies and skeletons to the Faculty of Medicine for medical research. The authors would like to thank to the support from Forensic Osteology Research Center,Faculty of Medicine, Chiang Mai University, and partially supported from Chiang Mai University. This work was supported by Faculty of Medicine, Chiang Mai University.

MONUM, T.; JONGMUENWAI, W.; THUNYACHAROEN, S.; SINTHUBUA, A.; PRASITWATTANASEREE, S. \& MAHAKKANUKRAUH, P. Estimación del sexo utilizando la ulna en una población tailandesa. Int. J. Morphol., 39(6):1535$1542,2021$.

RESUMEN: La estimación del sexo a partir de restos óseos fragmentarios sigue siendo un desafío para el patólogo forense. Se ha informado de la utilidad de la ulna para la estimación del sexo 
mediante análisis métrico. En este estudio se analizó la estimación del sexo para un fragmento y de la ulna completa en una población tailandesa. La función se generó a partir de 200 pares de ulnas y se utilizaron otras 20 pares de ulnas estimando la precisión de las funciones. El ancho del olécranon fue la mejor variable individual para predecir el sexo en la parte proximal de la ulna (90, $5 \%$ ). Si bien el ancho del extremo distal de la ulna fue la variable para predecir el sexo, el ancho del extremo distal izquierdo podría clasificarse por sexo con un 83,0 \% de certeza. Se aplicó un análisis de función discriminante escalonada a la parte proximal. Para la parte proximal de la ulna derecha se seleccionaron 4 medidas (longitud de la incisura troclear inferior-medial, ancho del olécranon, longitud del proceso olecraneano-proceso coronoides y ancho ulnar proximal máximo), mientras que en el lado izquierdo, fue determinado el ancho de la incisura superior troclear, ancho del olécranon y ancho ulnar proximal máximo. Se eligió el ancho, y se pudo predecir el sexo en el $91,0 \%$ y $90,0 \%$ de los casos, respectivamente. Nuestros resultados indicaron que la ulna tenía una alta capacidad para estimar el sexo en una población tailandesa.

PALABRAS CLAVE: Análisis de función discriminante; Análisis métrico; Estimación del sexo; Tailandia; Ulna.

\section{REFERENCES}

Barrier, I. L. O. \& L'Abbé, E. N. Sex determination from the radius and ulna in a modern South African sample. Forensic Sci. Int., 179(1):85.e17, 2008.

Charisi, D.; Eliopoulos, C.; Vanna, V.; Koilias, C. G. \& Manolis, S. K. Sexual dimorphism of the arm bones in a modern greek population. $J$. Forensic. Sci., 56(1):10-8, 2011.

Christensen, A. M.; Passalacqua, N. V. \& Bartelink, E. J. Forensic Anthropology: Current Methods and Practice. 2nd ed. Amsterdam, Academic Press, 2019.

Cowal, L. S. \& Pastor, R. F. Dimensional variation in the proximal ulna: evaluation of a metric method for sex assessment. Am. J. Phys. Anthropol., 135(4):469-78, 2008.

DiGangi, E. A. \& Moore, M. K. Research Methods in Human Skeletal Biology. Amsterdam, Elsevier Academic, 2013.

Jaruratanasirikul, S. \& Sriplung, H. Secular trends of growth and pubertal maturation of school children in Southern Thailand. Ann. Hum. Biol., 42(5):447-54, 2015.

Jordan, S.; Lim, L.; Seubsman, S. A.; Bain, C.; Sleigh, A. \& the Thai Cohort Study Team. Secular changes and predictors of adult height for 86105 male and female members of the Thai Cohort Study born between 1940 and 1990. J. Epidemiol. Community Health, 66(1):7580, 2012.

Kearns, A. An Evaluation of a Metric Method for Sex Estimation using the Clavicle, Humerus, Radius, and Ulna. Theses. Boston, Boston University, 2015.

Klepinger, L. L. Fundamentals of Forensic Anthropology. New York, John Wiley \& Sons, 2006.

Knapp, T. R. Technical error of measurement: A methodological critique. Am. J. Phys. Anthropol., 87(2):235-6, 1992.

Mall, G.; Hubig, M.; Büttner, A.; Kuznik, J.; Penning, R. \& Graw, M. Sex determination and estimation of stature from the long bones of the arm. Forensic Sci. Int., 117(1-2):23-30, 2001.

Purkait, R. Measurements of ulna--a new method for determination of sex. J. Forensic Sci., 46(4):924-7, 2001.
Ruff, C. B. \& Jones, H. H. Bilateral asymmetry in cortical bone of the humerus and tibia-sex and age factors. Hum. Biol., 53(1):69-86, 1981.

Safont, S.; Malgosa, A. \& Subira, M. E. Sex assessment on the basis of long bone circumference. Am. J. Phys. Anthropol., 113(3):317-28, 2000.

Sakaue, K. Sexual determination of long bones in recent Japanese. Anthropol. Sci., 112(1):75-81, 2004.

Seubsman, S. A. \& Sleigh, A. C. Change in mean height of Thai military recruits from 1972 through 2006. J. Epidemiol., 19(4):196-201, 2009.

Spradley, M. K. \& Jantz, R. L. Sex estimation in forensic anthropology: skull versus postcranial elements. J. Forensic Sci., 56(2):289-96, 2011.

Srivastava, R.; Saini, V.; Rai, R. K.; Pandey, S.; Singh, T. B.; Tripathi, S. K. \& Pandey, A. K. Sexual dimorphism in ulna: an osteometric study from India. J. Forensic Sci., 58(5):1251-6, 2013.

Suwanlikhit, N. Northern Thai Ulna and Sexing. Chiang Mai, Chiang Mai University, 2003.

Sweet, D. INTERPOL DVI best-practice standards--An overview. Forensic Sci. Int., 201(1-3):18-21, 2010.

Uzün, I.; Is san, M. Y. \& Celbis, O. Forearm bones and sexual variation in Turkish population. Am. J. Forensic Med. Pathol., 32(4):355-8, 2011.

Waghmare, J. E.; Deshmukh, P. R. \& Waghmare, P. J. Determination of sex from the shaft and tuberosity of radius- Amultivariate discriminant function analysis. Biomed. Res., 23(1):115-8, 2012.

Weinberg, S. M.; Scott, N. M.; Neiswanger, K. \& Marazita, M. L. Intraobserver error associated with measurements of the hand. Am. J. Hum. Biol., 17(3):368-71, 2005.

Corresponding author:

Prof. PasukMahakkanukrauh, MD

Department of Anatomy

Faculty of Medicine

Excellence in Osteology Research and Training Center (ORTC)

Chiang Mai University

Chiang Mai

THAILAND

E-mail: pasuk034@gmail.com

Received: 23-06-2021

Accepted:24-08-2021 